\title{
Meneropong Makna, Wacana Dan Pendekatan Dakwah Dalam Pembentukan Dan Pemberdayaan Masyarakat
}

\author{
Anas Habibi Ritonga \\ Fakultas Dakwah dan Ilmu Komunikasi IAIN Padangsidimpuan \\ (E-mail: anashabibi@gmail.com)
}

\begin{abstract}
The meaning, discourse and da'wah approach is a very urgent thing to study, because it really determines the success or failure of a da'wah that will ultimately shape and and follow the development of society, and other communities are dynamic creatures, changing according to the times. So it is necessary to do the current interpretation of how to form and develop Islamic society in accordance with the current context, and what discourse should be rolled out to encourage the formation and development of Islamic society and finally how the preaching approach should be carried out so that preaching is not monotonous left by the people. Empowerment is an effort to raise public awareness of the potential that is around them and try to develop these potentials with the aim of the community being able to become independent in all fields. This paper tries to look at the meaning, discourse and approach of da'wah in the formation and empowerment of Islamic societies and also how to function the da'wah approach in empowering Islamic societies.

Keywords: Meaning, Da'wah Approach, Formation and Empowerment of Islamic Communities
\end{abstract}

Abstrak: Makna, wacana dan pendekatan dakwah merupakan hal yang sangat urgen untuk dikaji, karena sangat menentukan sukses atau tidaknya sebuah dakwah yang pada akhirnya akan membentuk dan dan mengikuti perkembangan masyarakat, dan disii lain masyarakat adalah mahluk yang dinamis, berubah sesuai dengan perkembangan jaman. Maka perlu dilakukan pemaknaan terkini bagaimana melakukan pembentukan dan perkembangan masyarakat Islam yang sesuai dengan konteks kekinian, dan wacana apa yang harus digulirkan untuk mendorong pembentukan dan perkembangan masyarakat Islam dan terakhir bagaimana pendekatan dakwah yang mesti dilakukan agar dakwah itu tidak monoton yang ditinggalkan umat. Pemberdayaan merupakan upaya membangkitkan kesadaran masyarakat terhadap potensi yang ada di sekitarnya serta berusaha untuk melakukan pengembangan terhadap potensi tersebut dengan tujuan masyarakat tersebut dapat menjadi mandiri dalam segala bidang. Tulisan ini mencoba untuk melihat makna, wacana dan pendekatan dakwah dalam pembentukan dan pemberdayaan 
129 Anas Habibis Ritonga, Meneropong Makna, Wacana dan Pendekatan Dakwah dan Pemberdayaan Masyarakat

Jurnal At-Taghyir : Jurnal Dakwah dan Pengembangan Masyarakat Desa

Volume 2 Nomor 1 Desember 2019, h. 128-145

masyarakat Islam dan bagaimana pula fungsi pendekatan dakwah dalam pemberdayaan masyarakat Islam.

Kata Kunci: Makna, Pendekatan Dakwah, Pembentukan dan Pemberdayaan Masyarakat Islam

\section{A. Pendahuluan}

Dakwah merupakan "the salvation movement" atau aktivitas menyelamatkan umat dari kehancuran hidup, pembebasan dari kenistaan dan cengkeraman dari kemewahan dunia. Aktivitas dakwah harus menjadi bagian dari dinamika kehidupan dan usaha yang sungguh-sungguh yang sangat menentukan keberhasilan hidup manusia. Oleh sebab itu, aktivitas dakwah tidak akan berhenti dalam arti kata harus terus dilakukan usaha pembaharuan terhadap makna, wacana dan pendekatan yang relevan dengan persoalan sisi kehidupan manusia. Peninjauan ulang terhadap makna, wacana dan pendekatan dakwah sebaiknya dihubungkan dengan persoalan hidup secara menyeluruh dan komprehensif, di sebabkan segala sesuatu memiliki hubungan antar yang satu dengan yang lainnya.

Jika merujuk kepada apa yang dicontohkan oleh Rasulullah Saw, di saat membangun masyarakat, setidaknya harus ditempuh tiga tahapan atau proses pengembangan masyarakat, yaitu takwin, tanzim, dan taudi'. Takwin adalah tahap pembentukan masyarakat, dan tanzim adalah tahap pembinaan dan penataan masyarakat, sedangkan taudi' adalah tahap pelepasan dan kemandirian umat. Di sisi lain, pemberdayaan masyarakat sebagai suatu konsep perubahan sosial harus diakui untuk selalu mengacu dan berpijak pada paradigma pembangunan berbasis masyarakat, jangan sampai terjebak pada proses rekayasa sosial yang akan menempatkan masyarakat sekadar sebagai objek pemilik kepentingan saja.

Jika dikaitkan antara dakwah dan aktivitas pemberdayaan masyarakat terlihat benang merah antara keduanya, saling mengisi antara yang satu dengan yang lainnya. Misalnya saja dakwah adalah aktivitas memotivasi atau mendorong umat untuk melakukan kebaikan dan mengikuti petunjuk serta menyuruh berbuat yang "ma'ruf" dan mencegah berbuat yang "munkar" agar manusia memperoleh kebahagiaan yang hakiki baik ketika di dunia maupun nanti saat berada di akhirat. Di sisi lain pemberdayaan masyarakat adalah aktivitas meningkatkan harkat dan martabat sebuah masyarakat yang 
130 Anas Habibis Ritonga, Meneropong Makna, Wacana dan Pendekatan Dakwah dan Pemberdayaan Masyarakat

Jurnal At-Taghyir : Jurnal Dakwah dan Pengembangan Masyarakat Desa

Volume 2 Nomor 1 Desember 2019, h. 128-145

dalam kondisi sekarang belum mampu untuk melepaskan diri dari jeratan kemiskinan dan jeratan keterbelakangan.

Selanjutnya bahwa ada semacam pemisahan yang terjadi pada kalangan masyarakat, antara aktivitas "dakwah” (yang terkesan konsep umat Islam) dengan aktivitas "pemberdayaan masyarakat" (yang terkesan memakai konsep Barat), seolaholah keduanya saling bertentangan. Oleh sebab itu, tulisan ini untuk meneropong makna, wacana dan pendekatan dakwah dalam pembentukan dan pengembangan masyarakat.

\section{B. Makna Dakwah dan Pemberdayaan Masyarakat Islam}

1. Makna dan Tujuan Dakwah

Dakwah secara bahasa berasal dari bahasa Arab "da'wah/دعو" Dakwah memiliki kata dasar "dal-'ain-wawu/,$-\varepsilon-د$. Dari ketiga huruf tersebut, terbentuk berbagai kata dengan corak arti yang berbeda. Arti-arti tersebut diantaranya; menyuruh datang, mendorong, menyebabkan, mendatangkan, mendo'akan, menangisi, dan meratapi, memanggil, mengundang, minta tolong, meminta, memohon, menamakan. ${ }^{1}$

Secara istilah definisi dakwah berkembang sesuai dengan perkembangan dakwah aplikatif dan keilmuan dakwah itu sendiri. Memang tidak dapat dipungkiri bahwa secara aplikatif dakwah telah ada sejak Rasulullah Saw. menyampaikan ajaran Islam. Tetapi keilmuan dakwah baru berkembang pada masa sekarang ini. Maka dari itu, pengertian dakwah setidaknya harus merujuk terhadap Kitabullah dan tujuan agama Islam, jangan sampai merujuk kepada golongan atau firqah yang diyakini. Hal ini untuk menghindari kerancuan pengertian dakwah oleh berbagai firqah yang ada.

Effendi Zarkasyi mendefiniskan dakwah sebagai kegiatan yang memfokuskan diri guna merubah iklim kehidupan yang lebih islami dan mapan sesuai dengan kehendak dan tuntutan agama. Sedangkan Isa Anshari berpendapat bahwa dakwah merupakan kegiatan yang membuat konfrontasi ketauhidan di tengah umat, membuat kemungkinan bagi kemanusiaan untuk menentukan pilihannya sendiri tanpa ada paksaan dari pihak lain. Sementara Muhammad al-Bahy menyatakan bahwa dakwah

\footnotetext{
${ }^{1}$ Muhammad Ali Aziz, Ilmu Dakwah, (Jakarta: Prenada Media Group, 2009), hlm. 6. Lihat juga Muhammad Sulthon, Desain Ilmu Dakwah: Kajian Ontologis, Epistemologis dan Aksiologis, (Yogyakarta: Pustaka Pelajar, 2003), hlm. 4. Samsul Munir Amin, Ilmu Dakwah, (Jakarta: Amzah, 2009), hlm. 1 .
} 
131 Anas Habibis Ritonga, Meneropong Makna, Wacana dan Pendekatan Dakwah dan Pemberdayaan Masyarakat

Jurnal At-Taghyir : Jurnal Dakwah dan Pengembangan Masyarakat Desa

Volume 2 Nomor 1 Desember 2019, h. 128-145

islmaiyah merupakan seruan terhadap acuan nilai-nilai kemanusiaan dalam perilaku sehari-hari baik yang berhubungan dengan antar sesama manusia dan perilaku manusia dengan makhluk lainnya.

Adapun Thoha Yahya Umar berkomentar bahwa dakwah meupakan kegiatan menyeru umat dengan metode yang bijaksana untuk hidup di jalan yang benar sesuai dengan petunjuk Allah demi mencapai kemaslahatan dan kebahagiaan umat baik di dunia maupun di akhirat nanti. Ahli dakwah lain, seperti Ibn Taimiyah mendefiniskan dakwah sebagai satu proses kegiatan demi menyeru agar manusia percaya kepada Allah, percaya dan taat terhadap apa saja yang telah disampaikan oleh rasul-Nya dan menyeru umat supaya dalam menyembah kepada Allah seolah-olah melihat-Nya. Lain lagi dengan Al-Bahy al-Khauly berpendapat bahwa dakwah merupakan usaha untuk melakukan perubahan suatu kondisi menuju kondisi yang lebih baik dan layak, terhadap lingkup pribadi maupun kelompok masyarakat. Sementara Ra'uf Syalaby berpendapat bahwa dakwah merupakan suatu harakah untuk mengaplikasikan aturan-aturan yang Allah berikan yang telah dibawakan nabi-Nya yaitu nabi Muhammad Saw.

Sementara Syekh Ali Mahfudz menyatakan bahwa dakwah adalah memotivasi atau mendorong umat untuk melakukan kebaikan dan mengikuti petunjuk serta menyuruh berbuat yang "ma'ruf" dan mencegah berbuat yang "munkar" agar manusia memperoleh kebahagiaan yang hakiki baik ketika di dunia maupun nanti saat berada di akhirat. Berbeda lagi dengan Nasaruddin Latif mengartikan dakwah merupakan kegiatan atau perbuatan baik dengan menggunakan dengan "lisan" maupun menggunakan dengan "tulisan", dan sebagainya yang memiliki sifat untuk seruan, ajakan, panggilan terhadap umat lainnya untuk beriman dan taati kepada Allah Swt, berdasarkan aturan-aturan kenyakinan, aturan serta akhlak yang Islami. ${ }^{2}$ Muhammad Ali Aziz mengumpulkan tiga puluh delapan definisi dakwah, diantaranya adalah:

a. "Merupakan usaha para ulama dan orang-orang yang memiliki pengetahuan agama Islam untuk memberikan pengajaran kepada umat sesuai dengan kemampuan yang dimilikinya terkait hal-hal yang mereka butuhkan dalam urusan dunia dan keagamaan", demikian pendapat Abu Bakar Zakaria terkait definisi dakwah,

b. "Pedoman hidup yang sempurna untuk umat beserta ketetapan hak dan kewajibannya", adalah pendapat Syekh Muhammad al-Rawi terkait definisi dakwah,

\footnotetext{
${ }^{2}$ Muhammad Sulthon, Op.cit. hlm. 8-9.
} 
132 Anas Habibis Ritonga, Meneropong Makna, Wacana dan Pendekatan Dakwah dan Pemberdayaan Masyarakat

Jurnal At-Taghyir : Jurnal Dakwah dan Pengembangan Masyarakat Desa

Volume 2 Nomor 1 Desember 2019, h. 128-145

c. "Suatu sistem yang bertujuan memberikan penjelasan terhadap kebenaran, kebajikan, dan petunjuk atau agama sekaligus mengungkapkan berbagai kejahatan beserta media dan metodenya melalui berbagai cara, teknik, metode, dan media yang ada", demikian pendapat Syekh Ali ibn Sahlih al-Mursyd memahami definisi dari dakwah,

d. "Mengajak umat menuju kebajikan dan melarang umat melakukan kemungkaran supaya mendapatkan kebahagiaan di dunia dan di akhirat" definisi dakwah menurut Syekh Muhammad al-Khadir Husain,

e. "Sebuah program yang paripurna yang mengumpulkan seluruh pengetahuan yang dibutuhkan oleh umat pada semua bidang, agar umat bisa memahami tujuan hidupnya, serta menyelidiki petunjuk jalan yang mengarahkannya menjadi manusia yang mendapatkan petunjuk", demikian Al-Ghazali memberikan definisi dakwah. ${ }^{3}$

Dari definisi yang disampaikan berbagai para pakar tersebut dapat dipahami sesungguhnya terdapat beberapa komponen dakwah antara satu definisi dengan definisi lainnya, yaitu; da'i (individu atau komunitas), mad'u (objek dakwah/mitra dakwah), media, metode, materi (doktrin Islam), dan tujuan dakwah. Dengan demikian dakwah merupakan seluruh kegiatan seseorang yang memiliki maksud untuk memanggil atau menyeru orang lain menuju kepada jalan Allah atau "doktrin Islam" dengan memakai berbagai pendekatan dan metode yang cocok agar umat yang diajak atau dipanggil tersebut mau dan mampu hidup selaras dan harmonis, serta bahagia di dunia dan di akhirat. Merujuk definisi di atas bahwa dakwah merupakan semua kegiatan yang bermaksud mengajak umat menuju aturan Allah Swt. Di samping itu, dakwah sebagai sebuah aktivitas tentunya memiliki identitas yang melekat sebagai suatu yang eksis (almaujud).

Terkait dari tujuan dakwah, para ahli mengungkapkan definisi yang berbedabeda. Namun perbedaan pendapat tersebut hanyalah dalam tataran redaksi bahasa, hal ini disebabkan karena proses kegiatan dakwah yang dilaksanakan masing-masing dalam rangka mencapai nilai-nilai tertentu sesuai dengan situasi dan kondisi yang ada. Sesuatu yang dicapai melalui tindakan, perbuatan atau usaha dinamakan dengan "tujuan". Dikaitkan dengan dakwah, maka yang dimaksud dengan tujuan dakwah sebagaimana dikatakan Ahmad Ghasully dalam Pimay adalah memandu umat melakukan kebaikan guna mendapatkan kebahagiaan. Sedangkan Ra'uf Syalaby mengatakan bahwa tujuan dakwah adalah mentauhidkan Allah Swt, menjadikan umat patuh kepada Allah Swt,

\footnotetext{
${ }^{3}$ Muhammad Ali Aziz. Op.Cit, hlm. 11-16.
} 
133 Anas Habibis Ritonga, Meneropong Makna, Wacana dan Pendekatan Dakwah dan Pemberdayaan Masyarakat

Jurnal At-Taghyir : Jurnal Dakwah dan Pengembangan Masyarakat Desa

Volume 2 Nomor 1 Desember 2019, h. 128-145

mentaqarrubkan diri kepada Allah Swt serta melakukan intropeksi diri terhadap apa saja yang telah dilakukan selama ini. ${ }^{4}$

Tujuan dakwah sebagaimana dikatakan Ahmad Ghasully dan Ra'uf Syalaby tersebut dapat dirumuskan ke dalam tiga bentuk tujuan yaitu:

a. Praktis

Tujuan praktis dakwah merupakan tujuan langkah pertama untuk menyalamatkan umat manusia dari lembah kehinaan dan membawanya ke tempat yang penuh kemuliaan, dari jalan yang bengkok kepada jalan yang penuh hidayah, dari lembah kesyirikan dengan segala bentuk penderitaan kepada dunia ketauhidan yang pasti nanti di akhirat mendapatkan kebahagiaan. Inilah ungkapan Qur'an surah al-Thalaq: 11.

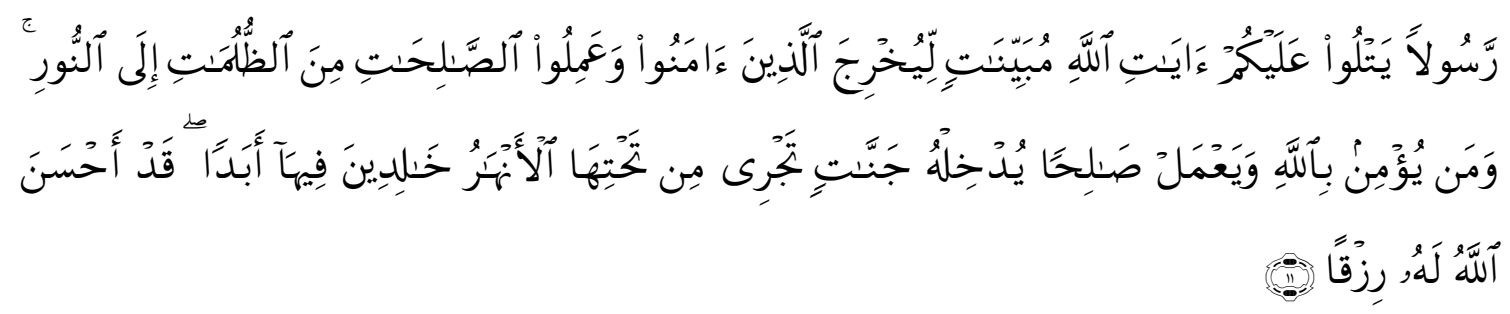

“(dan mengutus) seorang Rasul yang membacakan kepadamu ayat-ayat Allah yang menerangkan (bermacam-macam hukum) supaya Dia mengeluarkan orang-orang yang beriman dan beramal saleh dari kegelapan kepada cahaya. dan Barangsiapa beriman kepada Allah dan mengerjakan amal yang saleh niscaya Allah akan memasukkannya ke dalam surga-surga yang mengalir di bawahnya sungai-sungai; mereka kekal di dalamnya selama-lamanya. Sesungguhnya Allah memberikan rezki yang baik kepadanya." ${ }^{5}$

Secara praktis tujuan dakwah adalah menyelamatkan umat dari jurang yang gelap atau "kekafiran" yang membuatnya tidak bisa melihat segala bentuk kebenaran dan membawanya ketempat yang terang-benderang atau "cahaya iman" yang dipantulkan ajaran Islam sehingga mereka dapat melihat kebenaran.

b. "Realistis"

Tujuan realistis dakwah adalah berupa terlaksananya ajaran Islam secara "kaffah" dengan cara yang benar dan berdasarkan keimanan, sehingga terwujud "umah" yang menjunjung tinggi kehidupan beragama dengan mengimplementasikan ajaran Islam secara penuh dan menyeluruh dalam kehidupan sehari-hari.

\footnotetext{
${ }^{4}$ Awaluddin Pimay, Metodologi Dakwah (Semarang: Rasail, 2006), hlm. 9

${ }^{5}$ QS At-Thalaq; 11
} 
134 Anas Habibis Ritonga, Meneropong Makna, Wacana dan Pendekatan Dakwah dan Pemberdayaan Masyarakat

Jurnal At-Taghyir : Jurnal Dakwah dan Pengembangan Masyarakat Desa

Volume 2 Nomor 1 Desember 2019, h. 128-145

c. "Idealis"

Tujuan idealistis dakwah adalah terwujudnya masyarakat muslim yang diidamidamkan dalam suatu tatanan hidup berbangsa dan bernegara, adil, makmur, damai dan sejahtera di bawah limpahan rahmat, karunia dan ampunan Allah Swt. ${ }^{6}$ Lain lagi dengan Moh. Ali Aziz yang mengungkapkan bahwa tujuan dakwah yaitu:

a. Menghidupkan hati yang mati.

b. Mendapatkan ampunan dan menghindarkan azab dari Allah.

c. Menyembah Allah dan tidak menyekutukan-Nya.

d. Menegakkan agama dan tidak pecah belah.

e. Menyeru dan menuntun ke jalan yang lurus.

f. Menghilangkan dinding penutup sampainya ayat-ayat Allah Swt ke dalam qalbu hati umat. ${ }^{7}$

\section{Makna dan Tujuan Pemberdayaan Masyarakat Islam}

Secara harfiah kata pemberdayaan diartikan sebagai "pemberkuasaan", dalam arti pemberian atau peningkatan "kekuasaan" atau power kepada masyarakat yang kurang beruntung. Definisi pemberdayaan mempunyai arti yang sangat luas jika dilihat dari berbagai sisi. Perlu melakukan kajian terhadap beberapa pendapat para ahli pemberdayaan yang memiliki profesionalisme terhadap pemberdayaan masyarakat agar dapat memahaminya secara komprehensif.

Terkait dengan hal ini, Robinson menjelaskan bahwa pemberdayaan merupakan kegiatan proses pada person dan kelompok sosial; kegiatan membebaskan kemampuan pribadi, kompetensi pribadi, kreativitas pribadi dan kebebasan pribadi dalam hal bertindak. ${ }^{8}$ Ahli pemberdayaan, Jime Ife memaparkan bahwa pemberdayaan yang berlandaskan kepada kata "empowerment," bisa diartikan sebagai usaha memberika daya, memberikan power atau kekuasaan, maupun kekuatan, terhadap pihak yang lemah, dan tidak berdaya. ${ }^{9}$

Maka pada hakikatnya pemberdayaan bertujuan untuk membantu masyarakat supaya memiliki daya, kekuatan dan kemampuan untuk mengambil keputusan maupun

\footnotetext{
${ }^{6}$ Awaluddin Pimay, Paradigma Dakwah Humanis: Strategi dan Metode Dakwah Prof. KH Syaifuddin Zuhri, (Semarang: Rasail, 2005), hlm. 35-38

${ }^{7}$ Moh. Ali Aziz, Ilmu Dakwah, (Jakarta: Kencana, 2004), hlm. 60-63

${ }^{8}$ Robinson, J.R.. Community Development in Perspective. (Ames: Iowa State University Press, 1994), hlm. 125

${ }^{9}$ Ife, J.W.. Community Development: Creating Community Alternatives, (Vision, Analysis and Practice: Longman. Australia, 1995), hlm. 182
} 
135 Anas Habibis Ritonga, Meneropong Makna, Wacana dan Pendekatan Dakwah dan Pemberdayaan Masyarakat

Jurnal At-Taghyir : Jurnal Dakwah dan Pengembangan Masyarakat Desa

Volume 2 Nomor 1 Desember 2019, h. 128-145

tindakan yang hendak dilakukan dan yang berhubungan dengan masyarakat tersebut, termasuk mengurangi kendala person dan keompok dalam melakukan suatu tindakan. Masyarakat yang sudah mendapatkan tujuan bersama dilakukan pemberdayaan melalui kemandirian, bahkan merupakan kewajiban untuk lebih melakukan pemberdayaan melalui usaha mereka sendiri dan diambil dari akumulasi pengetahuan, keterampilan serta sumber lainnya yang ada dalam rangka mencapai tujuan yang telah ditentukan tanpa tergantung pada pertolongan pihak luar.

Upaya untuk memberikan kesempatan dan kemampuan kepada kelompok masyarakat untuk berpartisipasi, melakukan negosiasi, mempengaruhi, dan mengendalikan kelembagaan masyarakat secara bertanggung jawab demi perbaikan kehidupannya juga merupakan makna dari pemberdayaan. Pemberdayaan secara sederhana juga dapat diartikan sebagai usaha untuk memberikan daya atau "empowerment" atau kekuatan atau "strength" kepada masyarakat lemah.

Jika dilihat dari sisi prosesnya, kegiatan pemberdayaan memiliki dua kecenderungan. Pertama, kegiatan pemberdayaan yang memfokuskan pada proses memberikan atau mengalihkan sebagian kekuatan, kekuasaana atau kemampuan kepada masyarakat agar mereka lebih berdaya. Kedua, kegiatan pemberdayaan yang memfokuskan kepada proses menstimulasi, mendorong atau memotivasi masyarakat agar mempunyai kemampuan atau keberdayaan dalam hal menentukan apa yang menjadi pilihan hidup mereka melalui proses komunikasi dua arah yang dilakukan.

Melihat pada pendapat tersebut dapat dilihat bahwa dalam konteks pemahaman dunia Barat, yang disebut dengan empowerment lebih merupakan "pemberian kekuasaan" daripada "pemberian daya". Pengertian tersebut sangat wajar tercipta mengingat lahirnya konsep pemberdayaan di dunia Barat merupakan kegiatan reaksi atau pergulatan dari kekuasaan, sedangkan dalam konteks Indonesia, yang disebut dengan pemberdayaan merupakan suatu usaha untuk memberikan daya kepada masyarakat, atau meningkatkan daya masyarakat. ${ }^{10}$

\footnotetext{
${ }^{10}$ Tri Winarti, Memahami Pemberdayaan Masyarakat Desa Partisipatif dalam Orientasi Pembangunan Masyarakat Desa Menyongsong Abad 21: Menuju Pemberdayaan Pelayanan Masyarakat, (Yogyakarta: Aditya Media, 1998), hlm. 75-76.
} 
136 Anas Habibis Ritonga, Meneropong Makna, Wacana dan Pendekatan Dakwah dan Pemberdayaan Masyarakat

Jurnal At-Taghyir : Jurnal Dakwah dan Pengembangan Masyarakat Desa

Volume 2 Nomor 1 Desember 2019, h. 128-145

Inti dari pemberdayaan paling tidak meliputi tiga hal yaitu pengembangan atau "enabling", memperkuat potensi atau daya atau "empowering", dan terciptanya kemandirian, jika dikaitkan dengan pemaknaan konsep pemberdayaan masyarakat. ${ }^{11}$

Setiap masyarakat pasti memiliki daya, namun terkadang mereka tidak menyadari atau daya tersebut masih belum diketahui secara eksplisit. Statemen ini didasarkan pada asumsi bahwa tidak ada masyarakat yang sama sekali tanpa memiliki daya. Sehingga hakikatnya pemberdayaan adalah penciptaan suasana atau iklim yang memungkinkan potensi masyarakat berkembang atau "enabling".

Di samping itu hendaknya pemberdayaan jangan menjebak masyarakat dalam perangkap ketergantungan (charity), pemberdayaan sebaliknya harus mengantarkan pada proses kemandirian. Oleh karena itu daya harus digali dan kemudian dikembangkan. Maka pemberdayaan adalah upaya untuk membangun daya, dengan cara mendorong, memotivasi dan membangkitkan kesadaran akan potensi yang dimiliki serta berupaya untuk mengembangkannya. ${ }^{12}$

Para ahli ilmu sosial dalam memberikan definisi pemberdayaan memiliki rumusan yang bervariasi dalam berbagai konteks dan bidang pembahasannya, hal yang demikian disebabkan belum adanya definisi yang tegas terkait konsep pemberdayaan itu sendiri. Oleh karena itu, agar dapat memahami secara mendalam terkait definisi pemberdayaan diperlukan kajian terhadap beberapa pendapat para ahli yang memiliki komitmen terhadap pemberdayaan masyarakat.

Pertama, kita pahami pengertian tentang pemberdayaan. Menurut Sulistiyani secara bahasa pemberdayaan berasal dari kata dasar "daya" yang berarti kekuatan atau kemampuan. ${ }^{13}$ Bertolak dari pengertian tersebut, maka pemberdayaan dapat dipahami sebagai suatu proses menuju berdaya atau proses pemberian daya (kekuatan atau kemampuan) kepada pihak yang belum berdaya. Kedua, pengertian tentang masyarakat, menurut Soetomo, masyarakat merupakan sekumpulan orang yang saling berinteraksi

\footnotetext{
${ }^{11}$ Ibid

${ }^{12}$ Ibid

${ }^{13}$ Sulistyani, Ambar T\& Rosidah.. Manajemen Sumber Daya Manusia : Konsep, Teori dan Pembangunan dalam Konteks Organisasi Publik, (Yogyakarta: Graha Ilmu, 2003), hlm. 77
} 
137 Anas Habibis Ritonga, Meneropong Makna, Wacana dan Pendekatan Dakwah dan Pemberdayaan Masyarakat

Jurnal At-Taghyir : Jurnal Dakwah dan Pengembangan Masyarakat Desa

Volume 2 Nomor 1 Desember 2019, h. 128-145

secara terus menerus, sehingga memunculkan relasi sosial yang terpola dan terorganisasi $^{14}$

Dalam proses pemberdayaan, masyarakat dibantu bagaimana merancang sebuah kegiatan sesuai dengan kemampuan yang dimiliki, bagaimana cara mengimplementasikan rancangan tersebut, serta bagaimana cara membangun strategi memperoleh sumber-sumber eksternal yang dibutuhkan sehingga memperoleh hasil optimal. Maka pemberdayaan masyarakat adalah sebuah kegiatan dalam bingkai usaha memperkuat apa yang sering disebut dengan "community self-reliance" atau "kemandirian". Dalam proses ini masyarakat diberikan pendampingan dalam hal membuat analisis terhadap masalah yang mereka hadapi, mereka dibantu dalam menemukan solusi dari masalah tersebut, serta diperlihatkan strategi dalam memanfaatkan berbagai "resources" yang mereka miliki dan mereka kuasai. ${ }^{15}$

Secara konseptual, pemberdayaan masyarakat adalah usaha meningkatkan harkat dan martabat sebuah masyarakat yang dalam kondisi sekarang belum mampu untuk melepaskan diri dari jeratan kemiskinan dan jeratan keterbelakangan, dengan bahasa sederhananya "memberdayakan dan memampukan masyarakat".16

Menurut Moh. Ali Aziz, dkk "Pemberdayaan masyarakat merupakan suatu proses di mana masyarakat, khususnya mereka yang kurang memiliki akses ke sumber daya pembangunan, didorong untuk meningkatkan kemandiriannya di dalam mengembangkan perikehidupan mereka. Pemberdayaan masyarakat juga merupakan proses siklus terus-menerus, proses partisipatif di mana anggota masyarakat bekerja sama dalam kelompok formal maupun informal untuk berbagi pengetahuan dan pengalaman serta berusaha mencapai tujuan bersama. Jadi, pemberdayaan masyarakat lebih merupakan suatu proses". ${ }^{17}$

Partisipasi masyarakat menjadi satu unsur pokok dalam strategi pemberdayaan dan pembangunan masyarakat, dengan alasan; pertama, partisipasi masyarakat

\footnotetext{
${ }^{14}$ Soetomo, Pemberdayaan Masyarakat, (Yogyakarta: Pustaka Pelajar, 2011), hlm. 25

15 Abu Huraerah, Pengorganisasian dan Pengembangan Masyarakat, (Bandung: Humaniora, 2008), hlm. 87

${ }^{16}$ Murdi Yatmo Hutomo, Tesis: Pemberdayaan Masyarakat Dalam Bidang Ekonomi Tinjaun Teoritik dan Implementasi, (Jakarta: Universitas Indonesia, 2001), hlm.10.

${ }^{17}$ Moh. Ali Aziz dkk, Dakwah Pemberdayaan Masyarakat, Paradigma Aksi Metodologi, (Yogyakarta: Pustaka Pesantren, 2005), hlm. 136
} 
138 Anas Habibis Ritonga, Meneropong Makna, Wacana dan Pendekatan Dakwah dan Pemberdayaan Masyarakat

Jurnal At-Taghyir : Jurnal Dakwah dan Pengembangan Masyarakat Desa

Volume 2 Nomor 1 Desember 2019, h. 128-145

merupakan satu perangkat ampuh untuk memobilisasi sumber daya lokal, mengorganisir serta membuka tenaga, kearifan, dan kreativitas masyarakat. Kedua, partisipasi masyarakat juga membantu upaya identifikasi dini terhadap kebutuhan masyarakat", maka dalam pemaknaan pemberdayaan masyarakat menurut Madekhan Ali yang mendefinisikan pemberdayaan masyarakat sebagai bentuk partisipasi untuk membebaskan diri mereka sendiri dari ketergantungan "psikis" maupun "fisik" ${ }^{18}$

Merujuk pada definisi dan teori para ahli tersebut, dalam tulisan ini pemberdayaan diartikan sebagai upaya dalam membangkitkan kesadaran terhadap potensi yang dimiliki masyarakat serta berupaya untuk mengembangkan potensi tersebut sehingga masyarakat tersebut dapat mencapai suatu keadaan yang mandiri dalam segala bidang.

Selanjutnya dapat juga dipahami bahwa pemberdayaan masyarakat adalah upaya untuk meningkatkan daya atau kekuatan pada masyarakat dengan cara memberikan dorongan, peluang, kesempatan, dan perlindungan dengan cara mengatur dan mengendalikan kegiatan masyarakat yang sedang diberikan pemberdayaan untuk mengembangkan potensi yang ada sehingga masyarakat tersebut dapat meningkatkan kemampuan dan mengaktualisasikan diri atau berpartisipasi melalui berbagai aktivitas pemberdayaan.

Sedangkan tujuan yang ingin dicapai dari sebuah pemberdayaan adalah untuk membentuk individu dan masyarakat menjadi "mandiri". Kemandirian masyarakat tersebut meliputi kemandirian dalam "berpikir", kemandirian dalam "bertindak" dan kemandirian dalam "mengendalikan" apa yang mereka lakukan tersebut.

Untuk menuju mandiri perlu dukungan kemampuan berupa sumber daya manusia yang utuh dengan kondisi kognitif, konatif, psikomotorik dan afektif, dan sumber daya lainnya yang bersifat fisik material. Maka kemandirian masyarakat adalah merupakan suatu kondisi yang dialami masyarakat yang ditandai oleh kemampuan untuk memikirkan, memutuskan serta melakukan sesuatu yang dipandang tepat demi mencapai pemecahan masalah-masalah yang dihadapi dengan mempergunakan daya

${ }^{18}$ Madekhan Ali, Orang Desa Anak Tiri Perubahan, (Malang: Averroes Press, 2007), hlm. 86 
139 Anas Habibis Ritonga, Meneropong Makna, Wacana dan Pendekatan Dakwah dan Pemberdayaan Masyarakat

Jurnal At-Taghyir : Jurnal Dakwah dan Pengembangan Masyarakat Desa

Volume 2 Nomor 1 Desember 2019, h. 128-145

dan kemampuan yang terdiri atas kemampuan kognitif, konatif, psikomotorik, dengan pengerahan sumber daya yang dimiliki oleh lingkungan internal masyarakat tersebut.

Kondisi "kognitif" pada hakikatnya merupakan kemampuan berpikir yang dilandasi oleh pengetahuan dan wawasan seorang atau masyarakat dalam rangka mencari solusi atas permasalahan yang dihadapi. Kondisi "konatif" merupakan suatu sikap perilaku masyarakat yang terbentuk yang diarahkan pada perilaku yang sensitif terhadap nilai-nilai pembangunan dan pemberdayaan.

Kondisi "afektif" adalah merupakan sense yang dimiliki oleh masyarakat yang diharapkan dapat pendiktean untuk mencapai ke berdaya an dalam sikap dan perilaku. Kemampuan psikomotorik merupakan kecakapan keterampilan yang dimiliki masyarakat sebagai upaya pendukung masyarakat dalam rangka melakukan aktivitas pembangunan.

Terjadinya ke berdaya an pada empat aspek tersebut (kognitif, konatif, afektif dan psikomotorik) dapat memberikan kontribusi pada terciptanya kemandirian masyarakat yang dicita-citakan, karena dengan demikian dalam masyarakat akan terjadi kecukupan wawasan yang dilengkapi dengan kecakapan keterampilan yang memadai, diperkuat oleh rasa memerlukan pembangunan dan perilaku sadar akan kebutuhannya tersebut, untuk mencapai kemandirian masyarakat diperlukan sebuah proses pembelajaran.

Dengan adanya proses pembelajaran yang terus menerus maka masyarakat secara bertahap akan memperoleh kemampuan atau daya dari waktu ke waktu, dengan demikian akan terakumulasi kemampuan yang memadai untuk mengantarkan kemandirian mereka, apa yang diharapkan dari pemberdayaan yang merupakan visualisasi dari pembangunan sosial ini diharapkan dapat mewujudkan komunitas yang baik dan masyarakat yang ideal di tengah-tengah masyarakat. ${ }^{19}$

\section{Fungsi Pendekatan Dakwah dalam Pemberdayaan Masyarakat}

Sjahudi Siradj mengutarakan tiga pendekatan dakwah, yaitu pendekatan budaya, pendekatan pendidikan, dan pendekatan psikologis. Pendekatan-pendekatan ini melihat lebih banyak pada kondisi mitra dakwah. Maka pendekatan dakwah merupakan titik hlm. 80-81

${ }^{19}$ Ambar Teguh, Kemitraan dan Model-model Pemberdayaan, (Yogyakarta: Graha Ilmu, 2004), 
140 Anas Habibis Ritonga, Meneropong Makna, Wacana dan Pendekatan Dakwah dan Pemberdayaan Masyarakat

Jurnal At-Taghyir : Jurnal Dakwah dan Pengembangan Masyarakat Desa

Volume 2 Nomor 1 Desember 2019, h. 128-145

tolak atau sudut pandang kita terhadap proses dakwah. Umumnya, dalam menentukan pendekatan dakwah didasarkan pada mitra dakwah dan suasana yang melingkupinya. Oleh karenanya da'i, metode dakwah, pesan dakwah, dan media dakwah harus menyesuaikan pada kondisi mitra dakwah. Hal yang hampir sama dikemukakan oleh Toto Tasmara, bahwa pendekatan dakwah adalah cara-cara yang dilakukan oleh seorang da'i atas dasar hikmah dan kasih sayang untuk mencapai suatu tujuan tertentu.

Selajutnya pendekatan yang terfokus pada mitra dakwah maksudnya adalah dengan menggunakan bidang-bidang kehidupan sosial masyarakat. Pendekatan dakwah model ini diantaranya pendekatan sosial-politik, pendekatan sosial-budaya, pendekatan sosial-ekonomi, dan pendekatan sosial-psikologis. Semua pendekatan di atas bisa disederhanakan dengan dua pendekatan yaitu pendekatan "dakwah struktural" dan pendekatan "dakwah kultural”. Dengan kata lain, pendekatan dakwah harus bertumpu pada suatu pandangan "human oriented" dengan menempatkan penghargaan yang mulia atas jiwa manusia.

Dakwah dapat dilakukan dengan "pendekatan kultural" dan "pendekatan struktural", dan kedua pendekatan tersebut telah diperankan oleh Nabi Muhammad Saw. Paling tidak ada tiga sikap umat Islam terhadap budaya atau kultural saat itu yaitu menerima, memperbaiki dan menolaknya. dakwah kultural berlangsung selama AlQur'an turun secara berangsur-angsur yaitu 22 tahun, baik di Mekah maupun di Madinah, sementara dakwah struktural berlangsung di Madinah selama sepuluh tahun. Sebagai contoh, dakwah kultural yang dilakukan oleh Nabi sebagai respon al-Qur'an terhadap budaya masyarakat Arab ketika Al-Qur'an diturunkan. ${ }^{20}$

Pendekatan dakwah struktural dalam hal ini merupakan sebuah kegiatan dakwah yang berupaya untuk memberikan penghargaan terhadap budaya yang tidak bertentangan dengan ajaran Islam dan sekaligus usaha meng islamakan serta memanfaatkan masing-masing budaya yang ada untuk dijadikan sebagai alat pendekatan dakwah. Dakwah dalam model ini dapat dilakukan oleh da'i secara individu maupun secara kelompok melalui organisasi Islam atau organisasi dakwah. ${ }^{21}$

\footnotetext{
20 Abdullah, "Komplementaritas Dakwah Kultural dan Struktural," Jurnal Pengembangan Masyarakat UIN SU, Volume IV, No. 4, Tahun 2017, hlm. 1

${ }^{21}$ M. Mukhsin Jamil, Revitalisasi Islam Kultural, (Semarang: Walisongo Press, 2009), hlm. 164.
} 
141 Anas Habibis Ritonga, Meneropong Makna, Wacana dan Pendekatan Dakwah dan Pemberdayaan Masyarakat

Jurnal At-Taghyir : Jurnal Dakwah dan Pengembangan Masyarakat Desa

Volume 2 Nomor 1 Desember 2019, h. 128-145

Semua budaya yang bertentangan dengan Islam seperti kemungkaran, bid 'ah, khurafat dan maksiat menjadi sasaran perbaikan melalui dakwah "ishlah" dan pencegahan terhadap kemungkaran. Tugas tersebut dapat dilakukan secara peribadi maupun melalui organisasi dan kelompok, dengan melibatkan semua komponen masyarakat. Maka model dakwah kultural sebenarnya satu sisi berkompromi dengan budaya dan di sisi lain memiliki sikap yang tegas terhadap budaya yang ada. ${ }^{22}$

Proses dakwah yang menekankan pada si da'i untuk melakukan motivasi terhadap sasaran dakwahnya agar mau meyakini, mau memahami, mau menghayati dan mau mengamalkan ajaran Islam, dinamakan dengan dakwah kultural. Maka aktifitas ini sangat berhubungan dengan pikiran, hati dan kehendak seseorang yang menginginkan kesuksesan dalam hidupnya. Keberhasilan dakwah dalam hal ini, tidak hanya diukur dari reaksi sasaran dakwah pada pesan yang disampaikan, melainkan terjadinya penghayatan dan pengamalan nilai-nilai Islam dalam berbagai aspek kehidupan masyarakat. Untuk itu, da'i tidak hanya mampu menjelaskan kejayaan Islam masa lalu, kebesaran nama atau simbol-simbol Islam, tetapi harus memiliki semangat reformatif dan perubahan dalam melakukan kegiatan dakwahnya. ${ }^{23}$

Seperti definisi pendekatan dakwah tersebut yaitu menitik beratkan atau mengambil sudut pandang terhadap proses dakwah, maka ada juga pendekatan lain yang melibatkan semua unsur-unsur yang ada dalam dakwah, bukan sebatas dengan mitra dakwahnya. Karena sebuah "proses dakwah" berarti harus melibatkan semua unsurunsur yang ada dalam kegiatan dakwah tersebut. Dari pemahaman terebut di atas, maka paling tidak terdapat dua pendekatan dakwah yaitu:

\section{Pendekatan Dakwah Yang "Terpusat Pada Da'i”}

Pendekatan dakwah yang terpusat pada da'i menuntut agar unsur-unsur dakwah yang lainnya menyesuaikan atau bekerja sama sesuai dengan kemampuan da'i: pesan dakwah mana yang mampu dikuasai da'i, metode dakwah mana yang bisa dipakai oleh da'i, media dakwah mana yang mampu dimanfaatkan da'i. Maka pendekatan yang terpusat pada da'i bertujuan pada pelaksanaan kewajiban dakwah. Kewajiban da'i

\footnotetext{
${ }^{22}$ Abdullah, Komplementaritas..., hlm. 4

${ }^{23}$ Ali Buyung Sihombing, "Dakwah Kultural" dalam Majalah Miqot, Vol. xxvii, Nomor 1, Januari 2004, hlm. 181
} 
142 Anas Habibis Ritonga, Meneropong Makna, Wacana dan Pendekatan Dakwah dan Pemberdayaan Masyarakat

Jurnal At-Taghyir : Jurnal Dakwah dan Pengembangan Masyarakat Desa

Volume 2 Nomor 1 Desember 2019, h. 128-145

adalah menyampaikan pesan dakwah hingga mitra dakwah memahaminya atau diistilahkan dengan "al-balagh al-mubin". Aspek kognitif atau pemahaman mitra dakwah terhadap pesan dakwah lebih ditekankan dari pada aspek afektif atau sikap dan psikomotorik atau tingkah laku mereka. Fokusnya terletak pada kemampuan da'I, adapun targetnya adalah keberlangsungan dakwah itu sendiri.

2. Pendekatan Dakwah Yang "Terpusat Pada Mitra Dakwah"

Pendekatan dakwah yang terpusat pada mitra dakwah memfokuskan unsur-unsur dakwah yang ada terhadap upaya penerimaan mitra dakwah. Pendekatan ini berupaya merubah keagamaan mitra dakwah. Tidak hanya pada tingkat pemahaman, tetapi lebih dari itu, yaitu mengubah sikap dan perilaku mitra dakwah. Semua unsur-unsur dakwah harus menyesuaikan dengan kondisi mitra dakwah. Tidak semua orang dapat melakukan pendekatan ini. Karenanya, hukum berdakwah juga dapat dikatakan "fardlu kifayah" artinya hanya wajib bagi orang-orang yang telah memiliki kemampuan saja. Pertanyaan pokok pendekatan ini adalah bagaimana cara meningkatkan keimanan mitra dakwah. Sekali berdakwah tetapi menghasilkan perubahan keagamaan orang lebih baik dan lebih signifikan daripada beberapa kali berdakwah tetapi tidak menghasilkan perubahan apapun. ${ }^{24}$

Terkait kegiatan pemberdayaan, maka pendekatan yang akan dipakai, hendaknya harus memperhatikan poin-poin, diantaranya a). Tujuan yang ingin dicapai melalui kegiatan pemberdayaan, b). Transfer teknologi yang akan dilakukan, c). Pengembangan SDM/ fasilitator yang akan dilakukan pemberdayaan, d). Alternatif organisasi pemberdayaan yang akan diterapkan, yang berhadapan dengan pilihan 2: publik/ swasta, pemerintah/non, dari atas/dari bawah, mencari profit/ non profit, umum/ sektoral, multi tujuan/ tujuan tunggal, transfer teknologi/ orientasi kebutuhan. Di sampin itu, pemberdayaan dilakukan melalui tiga pendekatan yaitu mikro, mezzo, dan makro. Dimana pendekatan mikro yaitu pendekatan yang berpusat pada tugas, sedangkan pendekatan mezzo yaitu dilakukan terhadap sekelompok klien atau penerima manfaat, dan pendekatan Makro yaitu penerima manfaat diarahkan pada system lingkungan yang lebih luas.

\footnotetext{
${ }^{24}$ Moh. Ali Aziz, Ilmu Dakwah, (Jakarta: Kencana, 2004), hlm. 347
} 
143 Anas Habibis Ritonga, Meneropong Makna, Wacana dan Pendekatan Dakwah dan Pemberdayaan Masyarakat

Jurnal At-Taghyir : Jurnal Dakwah dan Pengembangan Masyarakat Desa

Volume 2 Nomor 1 Desember 2019, h. 128-145

Di pihak lain, pendekatan pemberdayaan dapat pula diformulasikan dengan mengacu kepada landasan filosofi dan prinsip-prinsip pemberdayaan yang ada,yang mencakup: 1) Pendekatan "partisipatif", yang mana kegiatannya menempatkan masyarakat sebagai titik-pusat pelaksanaan pemberdayaan, yang mencakup: a) Pemberdayaan bertujuan untuk memecahkan problem yang ada di tengah-tengah masyarakat, b) Pilihan kegiatan, metode maupun teknik pemberdayaan, maupun teknologi yang ditawarkan harus berbasis pada pilihan masyarakat, c) Ukuran keberhasilan masyarakat berdasarkan ukuran-ukuran masyarakat sebagai si penerima manfaat. 2) Pendekatan "Kesejahteraan", yang kegiatan dilakukan, yang dari mana pun sumber daya dan teknologi yang digunakan, dan siapa pun stakeholder nya, pemberdayaan masyarakat harus memberikan manfaat terhadap perbaikan mutu hidup dan kesejahteraan. 3) Pendekatan "Pembangunan berkelanjutan", dinama kegiatan pemberdayaan masyarakat harus terjamin keberlanjutannya dan tidak boleh menciptakan ketergantungan.

Pemberdayaan mayarakat hendaknya mengikuti pendekatan:

1. Upaya yang terarah (targeted), dalam artian kegiatan pemberdayaan masyarakat harus ditujukan langsung kepada yang memerlukan, dengan program yang dirancang untuk menyelesaikan masalah dan sesuai dengan apa yang dibutuhkan masyarakat yang menjadi sasarannya

2. Harus langsung mengikut sertakan atau bahkan dilaksanakan oleh masyarakat yang menjadi penerima manfaat. Masyarakat yang akan dibantu mempunyai maksud dan tujuan, iantaranya agar bantuan tersebut efektif karena sesuai dengan kehendak dan kemampuan serta kebutuhan mereka. Di samping itu, juga meningkatkan keberdayaan (empowering) masyarakat dengan pengalaman dalam melakukan rancangan, pelaksanaan, pengelolaan, dan pertanggungjawaban terhadap upaya peningkatan diri dan ekonomi mereka sendiri.

3. Menggunakan pendekatan kelompok. Pendekatan kelompok memiliki keunggulan dibanding sendiri-sendiri. Diantaranya masyarakat akan mudah memecahkan masalah-masalah yang dihadapinya jika ada dalam kelompok-kelompok, dan lingkup bantuan menjadi terarah apabila penanganannya dilakukan secara kelompok. 
144 Anas Habibis Ritonga, Meneropong Makna, Wacana dan Pendekatan Dakwah dan Pemberdayaan Masyarakat

Jurnal At-Taghyir : Jurnal Dakwah dan Pengembangan Masyarakat Desa

Volume 2 Nomor 1 Desember 2019, h. 128-145

\section{Penutup}

Umumnya, penentuan pendekatan didasarkan pada da'i dan mitra dakwah serta suasana yang melingkupinya. Maka jika kita lihat pendekatan dakwah dalam pemberdayaan masyarakat sangat menentukan sekali terhadap keberhasilan suatu kegiatan atau program-program yang dilakukan dalam kegiatan pemberdayaan masyarakat. Karena pendekatan dakwah adalah titik tolak atau sudut pandang kita terhadap proses dakwah. Pendekatan dakwah yang berpusat pada pendakwah dalam konteks pemberdayaan masyarakat diistilahkan dengan Top Down (Pemerintah menentukan program) yang biasanya ini kurang efektif karena tidak mengatasi masalah yang terjadi di tengah-tengah masyarakat. Adapun pendekatan dakwah yang berpusat pada mitra dakwah dalam hal pemberdayaan masyarakat diistilahkan dengan bottom up yang mana pendekatan ini sangat sesuai dengan efektif karena langsung terjun melihat kebutuhan masyarakat, dan masyarakat turut aktif dalam proses pemberdayaan masyarakat.

\section{Daftar Kepustakaan}

Abdullah, Komplementaritas Dakwah Kultural dan Struktural, Jurnal Pengembangan Masyarakat UIN SU, Volume IV, No. 4, Tahun 2017,

Abu Huraerah, Pengorganisasian dan Pengembangan Masyarakat, (Bandung: Humaniora, 2008),

Ali Buyung Sihombing, "Dakwah Kultural" dalam Majalah Miqot, vol. xxvii, Nomor 1, Januari 2004,

Ambar Teguh, Kemitraan dan Model-model Pemberdayaan, (Yogyakarta: Graha Ilmu, 2004),

Awaluddin Pimay, Metodologi Dakwah (Semarang: Rasail, 2006).

-------, Paradigma Dakwah Humanis: Strategi dan Metode Dakwah Prof. KH Syaifuddin Zuhri, (Semarang: Rasail, 2005),

Ife, J.W.. Community Development: Creating Community Alternatives, (Vision, Analysis and Practice: Longman. Australia, 1995),

M. Mukhsin Jamil, Revitalisasi Islam Kultural (Semarang: Walisongo Press, 2009),

Madekhan Ali, Orang Desa Anak Tiri Perubahan, (Malang, Averroes Press. 2007)

Moh. Ali Aziz dkk, Dakwah Pemberdayaan Masyarakat, Paradigma Aksi Metodologi, (Yogyakarta, Pustaka Pesantren, 2005),

Moh. Ali Aziz, Ilmu Dakwah, (Jakarta: Kencana, 2004),

Muhammad Ali Aziz. Ilmu Dakwah. Jakarta: Prenada Media Group, 2009,

Muhammad Sulthon. Desain Ilmu Dakwah: Kajian Ontologis, Epistemologis dan Aksiologis. Yogyakarta: Pustaka Pelajar, 2003, 
145 Anas Habibis Ritonga, Meneropong Makna, Wacana dan Pendekatan Dakwah dan Pemberdayaan Masyarakat

Jurnal At-Taghyir : Jurnal Dakwah dan Pengembangan Masyarakat Desa

Volume 2 Nomor 1 Desember 2019, h. 128-145

Murdi Yatmo Hutomo, Pemberdayaan Masyarakat Dalam Bidang Ekonomi Tinjaun Teoritik dan Implementasi (Tesis, Universitas Indonesia, Jakarta, 2001),

Robinson, J.R.. Community Development in Perspective. (Ames: Iowa State University Press, 1994)

Samsul Munir Amin. Ilmu Dakwah. Jakarta: Amzah, 2009,

Soetomo, Pemberdayaan Masyarakat. (Yogyakarta, Pustaka Pelajar, 2011),

Sulistyani, Ambar T\& Rosidah.. Manajemen Sumber Daya Manusia : Konsep, Teori dan Pembangunan dalam Konteks Organisasi Publik. (Yogyakarta : Graha Ilmu, 2003,

Tri Winarti, Memahami Pemberdayaan Masyarakat Desa Partisipatif dalam Orientasi Pembangunan Masyarakat Desa Menyongsong Abad 21: Menuju Pemberdayaan Pelayanan Masyarakat, (Yogyakarta: Aditya Media, 1998), 